\title{
Combining Ability Studies in Blackgram (Vigna mungo (L.) Hepper
}

\author{
Neeraj Ankur Toppo*, S. K. Nair and Abhinav Sao \\ Department of Genetics and Plant Breeding, College of Agriculture, Indira Gandhi \\ Krishi Vishwa Vidyalaya Raipur, 492012, Chhattishgarh, India \\ *Corresponding author
}

\section{A B S T R A C T}

K e y w o r d s
Blackgram,
GCA, SCA,
combining ability
Article Info
$\begin{aligned} & \text { Accepted: } \\ & 12 \text { February } 2020 \\ & \text { Available Online: } \\ & 10 \text { March } 2020\end{aligned}$

Keywords

Blackgram,

GCA, SCA,

rticle Info

12 February 2020 10 March 2020
7 parents and $21 \mathrm{~F}_{1}$ were analysed for combining ability during the Kharif2018 for days to $50 \%$ flowering, days to maturity, plant height, branches per plant, number of pods per plant, number of seeds per pod, pod length, seed yield per plant, harvest index, biological yield per plant, test weight and protein content. Among them INDIRA URD PRATHAM was observed as the best general combiner on the basis to GCA effects for most of the traits and TU-103 as early maturing and dwarf stature. TU-103 x LBG-623, Indira Urd Pratham x LBG-623 and Indira Urd Pratham x TU-94-2 was observed as the best hybrids for yield per plant on the basis of SCA effects.

\section{Introduction}

Blackgram (Vigna mungo (L.) Hepper) is an important pulse crop of India. It is a cheap source of dietary protein ( 24 per cent), which also contains 67 per cent carbohydrates, 3-5 per cent fibre and 1.74 per cent fat. It also contributes a major portion of lysine in the vegetarian diet and fairly good source of vitamins like thiamine, niacin, riboflavin and much needed iron and phosphorus.

It also has a wide range of economic value. It is well known that $50 \mathrm{~g}$. pulses/person /day should be consumed in addition to other sources of protein such as cereals, milk, meat and egg which is a very difficult task to achieve as the production and productivity of pulse crop including blackgram is very low. (Selvam and Elangaimannan, 2010). Diallel analysis, as proposed by Griffing (1956), measures the combining ability of parents to be used in hybridization and helps the crop breeder in choosing the desirable parents for hybridization program.

Besides this, diallel analysis also guides the breeder in choosing appropriate breeding method by estimating the GCA (general combining ability) and SCA (specific combining ability) variances governing the traits and by determining the components of 
genetic variance viz. additive and dominance variances assuming epistasis being absent. (Panigrahi et al., 2015). Nature of gene action controlling economic trait plays important role in crop improvement programme and the exploring the gene action is essential (Titumeer et al., 2014).

Combining ability study utilizing diallel analysis provides information on genetic component of variation. Study of GCA helps for selection of good combiners with additive genes and the SCA are helpful for the effect for superior hybrid combination.

Gene action is helpful for selection of breeding method for improvement of specific trait (Singh and Singh, 1974). Only additive type of gene action is fixable and essential to develop stable genotypes. Genetic variability study includes the parameter such as phenotypic, genotypic and environmental coefficient of variation, heritability and genetic advance are undeniably needed to start an efficient breeding method (Sarkar et al., 2014).

In case of highly self-pollinated crops heterosis cannot be directly exploited but vigorous hybrids can be used to be exploited for isolating transgressive segregants in advanced generation (Sharif et al., 2001). The study of heterosis provides the basis to determine genetic diversity and in selection of suitable cross combinations (Swindell and Poehlman, 1976).

\section{Materials and Methods}

Seven genotypes namely TU-103, MASH1008, INDIRA URD PRATHAM, PU-11-14, TU-94-2, LBG-623 and LBG-17 are used as parents in hybridization programme. The present investigation was carried out at research cum instructional farm, College of Agriculture, Indira Gandhi Krishi
Vishwavidyalaya, Raipur (CG.) during Kharif-2018. Genotypes were crossed in half diallel fashion. The parents and their resultant $21 \mathrm{~F}_{1}$ 's were evaluated in RBD with two replication with spacing of $30 \mathrm{~cm}$ x $10 \mathrm{~cm}$.

The observation were taken for 12 quantitative traits viz., days to $50 \%$ flowering, days to maturity, plant height, number of branches per plant, number of pods per plant, pod length, number of seeds per pod, 100 seed weight, biological yield per plant, seed yield per plant, harvest index and protein content. Analysis of data for general and specific combining ability was carried out following Griffing's (1956) Method II using the PB tool and AGRISTAT Software.

\section{Results and Discussion}

Identification of superior parents for their combining ability with corresponding parent is major goal of plant breeder for development of high yielding varieties. Relative breeding potential with nature and magnitude of gene action in expression of quantitative traits can be studied with combining ability analysis. Analysis of variance for the combining ability using diallel mating design (method 2) for 12 characters is given in Table 1.

Highly significant diversity recorded for most of the characters except for number of branches plant ${ }^{-1}$, pod length, number of seeds pod $^{-}$and 100 seed weight. This indicates the sufficiency of variation for selection.The GCA variances were higher over SCA variances for all the characters. It reveals the role of additive gene action in expression of trait. The GCA to SCA variance ratio ranged from 0.02 to 0.94. Panigrahi et al., (2015), Sevelam and Elangaimannam, (2010) and Dana and Dasgupta, (2001) also reported similar kind of results for yield and yield related traits in blackgram. 


\section{GCA effects}

Negative GCA effect for days to $50 \%$ flowering, days to maturity and plant height are desirable for development of early maturing and dwarf stature plant, while positive SCA effects are beneficial for most of the traits. INDIRA URD PRAATHM (1.73) showed significant gca effects for days to maturity and ranged from -1.73 to 1.27 , similar results reported by Haque et al., (2013). Plant height was varied from -8.63 to 7.14 , significant negative GCA effect found in TU-103 (-8.63), INDIRA URD PRATHAM (-5.41) and PU-11-14 (-4.63) these parents can be used for developing the dwarf stature plant.

Similar results for plant height was also reported by Haque et al., (2013), Dana and Dasgupta, (2001). Only one parent found significant positive general combiner for number of pods plant ${ }^{-1}$ is TU-94-2 (5.75) also suported by Kumari et al., (2012), Patel et al., (2010) and Chakraborty et al., (2010). Hence, this parent could be effectively used in further breeding programmes aimed at increasing number of pods per plant in blackgram. Only INDIRA URD PRATHAM was found significant positive general combiner for pod length. LBG-623 (0.32) and TU-103 (0.26) found as good general combiner for number of seeds pod $^{-1}$.

100 seed weight were ranged from -0.11 to 0.08 , parent TU-94-2 exhibited significant positive GCA effect, so this parent can be further used in breeding programme for larger seed size. Biological yield plant ${ }^{-1}$ were ranged from -9.20 to 9.78 in which Inidra Urd Pratham found significant positive effect,similar results also reported by Chakraborty et al., (2010). For seed yield plant $^{-1}$ only three parents found significant in which one showed positive GCA effect is Indira Urd Pratham (4.13) and remaining two showed negative GCA effect, Durgaprasad and Murugan, (2015), Panigrahi et al., (2015), Ram et al., (2013), Chakraborty et al., (2010) and Sevelam and Elangaimannan, (2010) also reported for seed yield per plant. Harvest index is found positive significant in TU-103 (1.91) and INDIRA URD PRATHAM (1.73), protein content is found positive significant for LBG-17 (1.83), LBG$623(0.76)$ and TU-103 (0.29). The GCA effect is shown in Table 1.2.

\section{SCA effect}

Crosses MASH-1008 x LBG-17 (-2.58, -4.86) and TU-103 x LBG-17 $(-1.08,-2.81)$ found as the significant specific combiner for days to $50 \%$ flowering and days to maturity Kachve et al., (2015), Haque et al., (2013), Ram et al., (2013), Chakraborty et al., (2010) reported similary. Plant height is ranged from -14.60 to 19.90 in which crosses TU-103 x LBG-17 (-14.60) found as the best specific combiner, similar result was reported by Rameshwari et al., (2011).

Cross TU-103 x LBG-17 is found as the best specific combiner for days to $50 \%$ flowering, days to maturity and plant height, so this cross can be used for the development of short duration and dwarf plant. Number of branches plant $^{-1}$ varied from -2.08 to 1.03 among them crosses MASH-1008 x TU-94-2 (1.03) and MASH-1008 x PU-11-14 (0.86) recorded as best specific combiner for the trait also reported by Panigrahi et al., (2015), Nahar $e t$ al., (2010), Sevelam and Elangaimannam, (2010) and Dana and Dasgupta, (2001).

Number of pods plant ${ }^{-1}$ varied from -8.53 to 15.53 among them crosses LBG-623 x LBG17 (15.53) and MASH-1008 x LBG-17 (11.86) are found as best specific combiner for the trait, result of present investigation also reported by Kumari et al., (2012), Patel et al., (2010) and Chakraborty et al., (2010). 
Table.1 Estimation of genetic components (combining ability) for seed yield and its attributing characters

\begin{tabular}{|c|c|c|c|c|c|c|c|c|c|c|c|c|c|}
\hline $\begin{array}{l}\text { Source of } \\
\text { variation }\end{array}$ & $\begin{array}{l}\text { d. } \\
\text { f. }\end{array}$ & $\begin{array}{c}\text { Days to } \\
50 \% \\
\text { flowering }\end{array}$ & $\begin{array}{c}\text { Days to } \\
\text { maturit } \\
y\end{array}$ & $\begin{array}{l}\text { Plant } \\
\text { height } \\
\text { (cm) }\end{array}$ & $\begin{array}{l}\text { Number of } \\
\text { branches } \\
\text { plant }^{-1}\end{array}$ & $\begin{array}{l}\text { Number of } \\
\text { pods plant }^{-1}\end{array}$ & $\begin{array}{c}\text { Pod } \\
\text { length } \\
\text { (cm) }\end{array}$ & $\begin{array}{c}\text { Number } \\
\text { of seeds } \\
\text { plant }^{-1}\end{array}$ & $\begin{array}{c}100 \text { seed } \\
\text { weight }(\mathrm{g})\end{array}$ & $\begin{array}{c}\text { Biological } \\
\text { yield plant }\end{array}$ & $\begin{array}{l}\text { Seed } \\
\text { yield } \\
\text { plant }^{-1}\end{array}$ & $\begin{array}{c}\text { Harvest } \\
\text { index } \\
(\%)\end{array}$ & $\begin{array}{c}\text { Protein } \\
\text { content } \\
(\%)\end{array}$ \\
\hline GCA & 6 & 2.07 & $8.45^{* * *}$ & $359.33 * *$ & 0.84 & $173.98 * *$ & 0.07 & 0.52 & 0.05 & $413.48 * *$ & $69.10 * *$ & $22.21 * *$ & $9.50 * *$ \\
\hline SCA & 21 & $2.49 * *$ & $8.59 * *$ & $68.86^{* *}$ & 0.82 & $69.68 * *$ & 0.15 & 0.48 & 0.24 & $146.44 * *$ & $22.68 * *$ & $13.71 * *$ & $4.86 * *$ \\
\hline Error $( \pm)$ & 27 & 1.65 & 3.28 & 8.41 & 0.59 & 28.71 & 0.052 & 0.16 & 0.005 & 110.55 & 16.33 & 4.57 & 0.0036 \\
\hline$\sigma^{2} g c a$ & & 0.05 & 0.57 & 38.99 & 0.03 & 16.14 & 0.0018 & 0.04 & 0.01 & 33.66 & 5.86 & 1.96 & 1.06 \\
\hline$\sigma^{2} s c a$ & & 0.84 & 5.31 & 60.45 & 0.23 & 41.27 & 0.10 & 0.32 & 0.24 & 35.89 & 6.35 & 9.14 & 4.85 \\
\hline$\underset{\text { ratio }}{\sigma^{2} g c a / \sigma^{2} g c a}$ & & 0.06 & 0.11 & 0.65 & 0.12 & 0.39 & 0.02 & 0.13 & 0.02 & 0.94 & 0.92 & 0.21 & 0.22 \\
\hline
\end{tabular}

$*$, ** Significant at $5 \%$ and $1 \%$ level of probability, respectively

Table.2 Estimates of general combining ability (GCA) effects of parents for seed yield and its attributing characters

\begin{tabular}{|c|c|c|c|c|c|c|c|c|c|c|c|c|}
\hline GCA effects & $\begin{array}{l}\text { Days to } \\
50 \% \\
\text { flowering }\end{array}$ & $\begin{array}{l}\text { Days to } \\
\text { maturity }\end{array}$ & $\begin{array}{l}\text { Plant } \\
\text { height } \\
\text { (cm) }\end{array}$ & $\begin{array}{l}\text { Number } \\
\text { of } \\
\text { branches } \\
\text { plant }^{-1}\end{array}$ & $\begin{array}{l}\text { Number } \\
\text { of pods } \\
\text { plant }^{-1}\end{array}$ & $\begin{array}{l}\text { Pod } \\
\text { length } \\
(\mathrm{cm})\end{array}$ & $\begin{array}{l}\text { Number } \\
\text { of seeds } \\
\text { pod }^{-1}\end{array}$ & $\begin{array}{l}100 \text { seed } \\
\text { weight } \\
\text { (g) }\end{array}$ & $\begin{array}{l}\text { Biological } \\
\text { yield } \\
\text { pplant }^{-1}\end{array}$ & $\begin{array}{l}\text { Seed } \\
\text { yield } \\
\text { plant }^{-1}\end{array}$ & $\begin{array}{l}\text { Harvest } \\
\text { index } \\
(\%)\end{array}$ & $\begin{array}{l}\text { Protein } \\
\text { content } \\
(\%)\end{array}$ \\
\hline TU-103 & -0.45 & -0.29 & $-8.63 * *$ & -0.33 & $-4.25 *$ & -0.06 & $0.26^{*}$ & $-0.10 * *$ & -1.69 & 0.05 & $1.91 * *$ & $0.29 * *$ \\
\hline MASH-1008 & 0.05 & 0.77 & 0.64 & 0.00 & 0.80 & -0.04 & $-0.29 *$ & 0.03 & -5.77 & $-2.59 *$ & -1.34 & $-1.39 * *$ \\
\hline $\begin{array}{l}\text { INDIRA URD } \\
\text { PRATHAM }\end{array}$ & -0.45 & $-1.73^{* *}$ & $-5.41 * *$ & -0.44 & 3.08 & $0.16^{*}$ & 0.15 & 0.04 & $9.78 * *$ & $4.13 * *$ & $1.73 *$ & $-0.43 * *$ \\
\hline PU-11-14 & -0.01 & -0.45 & $-4.63 * *$ & -0.06 & $-6.81 * *$ & -0.09 & -0.18 & $-0.11 * *$ & -9.20 & $-3.69 * *$ & -1.15 & -0.01 \\
\hline TU-94-2 & 0.55 & 0.38 & $6.75 * *$ & 0.22 & $5.75 *$ & -0.01 & -0.07 & $0.08 * *$ & 6.45 & 2.52 & 1.06 & $-0.46 * *$ \\
\hline LBG-623 & -0.40 & 0.05 & $7.14 * *$ & 0.22 & 2.63 & 0.08 & $0.32 *$ & 0.02 & -2.74 & -1.28 & $-1.97 * *$ & $0.76 * *$ \\
\hline LBG-17 & 0.71 & $1.27 *$ & $4.14 * *$ & 0.39 & -1.20 & -0.04 & -0.18 & 0.05 & 3.18 & 0.86 & -0.24 & $1.83 * *$ \\
\hline S.E (gi) \pm & 0.40 & 0.56 & 0.90 & 0.08 & 1.63 & 0.07 & 0.12 & 0.02 & 3.24 & 1.25 & 0.65 & 0.02 \\
\hline S.E (gi-gj) \pm & 0.76 & 0.86 & 1.37 & 0.12 & 2.48 & 0.11 & 0.19 & 0.03 & 4.04 & 1.90 & 1.00 & 0.03 \\
\hline
\end{tabular}

*** Significant at $5 \%$ and $1 \%$ level of probability, respectively 
Table.3 Estimates of specific combining ability (SCA) effects of crosses for seed yield per plant and its attributing characters

\begin{tabular}{|c|c|c|c|c|c|c|c|c|c|c|c|c|}
\hline $\begin{array}{c}\text { SCA } \\
\text { effects }\end{array}$ & $\begin{array}{c}\text { Days to } \\
50 \% \\
\text { flowering }\end{array}$ & $\begin{array}{c}\text { Days to } \\
\text { maturity }\end{array}$ & $\begin{array}{c}\text { Plant } \\
\text { height } \\
\text { (cm) }\end{array}$ & $\begin{array}{l}\text { Number of } \\
\text { branches }^{-1}\end{array}$ & $\begin{array}{c}\text { Number } \\
\text { of pods } \\
\text { plant }^{-1}\end{array}$ & $\begin{array}{c}\text { Pod } \\
\text { length } \\
\text { (cm) }\end{array}$ & $\begin{array}{c}\text { Number } \\
\text { of seeds } \\
\text { pod }^{-1}\end{array}$ & $\begin{array}{c}100 \text { seed } \\
\text { weight } \\
\text { (g) }\end{array}$ & $\begin{array}{c}\text { Biological } \\
\text { yield } \\
\text { plant }^{-1}\end{array}$ & $\begin{array}{c}\text { Seed } \\
\text { yield } \\
\text { plant }^{-1}\end{array}$ & $\begin{array}{c}\text { Harvest } \\
\text { index } \\
(\%)\end{array}$ & $\begin{array}{c}\text { Protein } \\
\text { content } \\
(\%)\end{array}$ \\
\hline $\begin{array}{c}\text { TU-103 x } \\
\text { MASH- } \\
1008\end{array}$ & $1.58 * *$ & -1.31 & $-3.10 *$ & $-0.92 * *$ & -0.58 & $-0.22 *$ & 0.01 & $0.10 * *$ & 1.17 & 0.77 & 0.89 & $1.99 * *$ \\
\hline $\begin{array}{l}\text { TU-103 x } \\
\text { IUP }\end{array}$ & $-1.42 *$ & 1.19 & -1.04 & 0.03 & 1.64 & $0.33^{* *}$ & $0.57 * *$ & $0.48 * *$ & -4.29 & -3.36 & $-4.78 * *$ & $0.49 * *$ \\
\hline $\begin{array}{l}\text { TU-103 x } \\
\text { PU-11-14 }\end{array}$ & 0.64 & 0.92 & $-8.82^{*}$ & -0.36 & -1.97 & $-0.92 * *$ & $-0.60 * *$ & $-1.36^{* *}$ & $-15.50 *$ & $-5.23 * *$ & -0.06 & $-1.54 * *$ \\
\hline $\begin{array}{c}\text { TU-103 x } \\
\text { TU-94-2 }\end{array}$ & -0.42 & $-2.92 * *$ & $-7.71 * *$ & 0.36 & $-8.53 * *$ & $0.50 * *$ & $-0.71 * *$ & $0.35^{* *}$ & $-9.37 *$ & -3.17 & 0.07 & $-1.39 * *$ \\
\hline $\begin{array}{l}\text { TU-103 x } \\
\text { LBG-623 }\end{array}$ & 0.53 & $2.42 * *$ & $19.90 * *$ & 0.36 & $13.58 * *$ & -0.08 & $0.40^{*}$ & $-0.19 * *$ & $28.77^{*}$ & $11.09 * *$ & $2.16^{*}$ & $0.40 * *$ \\
\hline $\begin{array}{c}\text { TU-103 x } \\
\text { LBG-17 }\end{array}$ & $-1.08 *$ & $-2.81 * *$ & $-14.60 *$ & -0.31 & -2.08 & $-0.22 *$ & $0.40 *$ & $-0.32 * *$ & $-18.27 *$ & $-5.68 * *$ & $3.75 * *$ & $-0.51 * *$ \\
\hline $\begin{array}{c}\text { MASH- } \\
1008 x \\
\text { IUP }\end{array}$ & -0.42 & $2.14 * *$ & -0.82 & $0.69 *$ & $-5.92 *$ & $-0.44 * *$ & $-0.88^{* *}$ & $-0.44 * *$ & $22.38^{*}$ & $-7.90 * *$ & -0.65 & $-2.13 * *$ \\
\hline $\begin{array}{c}\text { MASH- } \\
\text { 1008 x } \\
\text { PU-11-14 }\end{array}$ & 0.64 & $1.86^{*}$ & $5.40 * *$ & $0.81 *$ & $7.47 * *$ & $0.31 * *$ & $0.46^{* *}$ & $1.22 * *$ & 3.29 & 2.11 & $2.43 * *$ & $-1.54 * *$ \\
\hline $\begin{array}{c}\text { MASH- } \\
1008 x \\
\text { TU-94-2 }\end{array}$ & -0.92 & 1.03 & $7.01 * *$ & $1.03 * *$ & 0.42 & -0.03 & $-0.65 * *$ & $-0.17 * *$ & 1.98 & -0.76 & $-2.72 * *$ & $1.52 * *$ \\
\hline $\begin{array}{c}\text { MASH- } \\
1008 x \\
\text { LBG-623 }\end{array}$ & -0.47 & $-2.41 * *$ & $7.13 * *$ & 0.03 & 1.03 & $0.39 * *$ & -0.04 & $-0.32 * *$ & -7.82 & -2.95 & $-2.52 * *$ & $-3.89 * *$ \\
\hline MASH- & $-2.58 * *$ & $-4.86 * *$ & -1.88 & $0.86^{*}$ & $11.86 * *$ & -0.00 & -0.04 & $0.16^{* *}$ & 0.55 & 1.20 & $2.52 * *$ & $0.08 * *$ \\
\hline
\end{tabular}




\begin{tabular}{|c|c|c|c|c|c|c|c|c|c|c|c|c|}
\hline $\begin{array}{c}1008 x \\
\text { LBG-17 }\end{array}$ & & & & & & & & & & & & \\
\hline $\begin{array}{c}\text { IUP x } \\
\text { PU-11-14 }\end{array}$ & $2.14 * *$ & $3.86 * *$ & -1.04 & $0.75^{*}$ & $4.69 *$ & $0.36 * *$ & 0.01 & $-0.30 * *$ & -4.15 & -2.00 & -0.03 & $-0.96 * *$ \\
\hline $\begin{array}{c}\text { IUP x } \\
\text { TU-94-2 }\end{array}$ & 0.08 & 0.03 & 1.07 & -0.03 & $7.64 * *$ & $-0.72 * *$ & $-0.60 * *$ & $0.21 * *$ & 8.39 & $3.48 *$ & 1.10 & $-1.06 * *$ \\
\hline $\begin{array}{c}\text { IUP x } \\
\text { LBG-623 }\end{array}$ & $1.53 * *$ & $1.86^{*}$ & 1.68 & $-1.03 * *$ & 2.75 & -0.06 & $1.51 * *$ & $0.37 * *$ & $12.56^{*}$ & $6.77 * *$ & $6.37 * *$ & $2.21 * *$ \\
\hline $\begin{array}{c}\text { IUP x } \\
\text { LBG-17 }\end{array}$ & -0.08 & $-2.36 * *$ & $2.68 *$ & 0.31 & 2.58 & $0.31 * *$ & 0.01 & $0.19 * *$ & 6.74 & 3.23 & 1.51 & $-1.37 * *$ \\
\hline $\begin{array}{c}\text { PU-11-14 } \\
\text { x TU-94- } \\
2\end{array}$ & -0.36 & -1.25 & -2.21 & $-0.92 *$ & -1.47 & 0.03 & $0.74 * *$ & $0.07 *$ & -14.14 & -0.21 & $3.77 * *$ & $0.30 * *$ \\
\hline $\begin{array}{c}\text { PU-11-14 } \\
\text { x LBG- } \\
623\end{array}$ & -0.92 & -0.42 & $-7.10 * *$ & 0.08 & -3.86 & -0.06 & -0.15 & $0.22 * *$ & -3.86 & -0.31 & $3.78 * *$ & $-2.61 * *$ \\
\hline $\begin{array}{l}\text { PU-11-14 } \\
\text { x LBG-17 }\end{array}$ & -0.53 & $2.86 * *$ & $-2.60 *$ & $-2.08 * *$ & -2.03 & $-0.44 * *$ & $0.85^{* *}$ & $0.14 * *$ & 2.36 & -1.32 & $-6.91 * *$ & $-1.74 * *$ \\
\hline $\begin{array}{c}\text { TU-94-2 } \\
\text { x LBG- } \\
623\end{array}$ & $1.53 * *$ & 0.25 & $-9.49 * *$ & 0.31 & $6.58 * *$ & $0.36 * *$ & $0.74 * *$ & $0.13 * *$ & -6.86 & $-3.88 *$ & $-3.07 * *$ & $-0.64 * *$ \\
\hline $\begin{array}{c}\text { TU-94-2 } \\
\text { x LBG-17 }\end{array}$ & -0.08 & 0.03 & $-3.49 * *$ & $-1.36 * *$ & -1.58 & -0.03 & 0.24 & $-0.14 * *$ & -4.91 & -2.15 & -0.75 & $-1.17 * *$ \\
\hline $\begin{array}{l}\text { LBG-623 } \\
x \text { LBG-17 }\end{array}$ & $3.86 * *$ & $5.86 * *$ & $4.63 * *$ & 0.64 & $15.53 * *$ & -0.11 & $-1.15 * *$ & $-0.09 * *$ & -5.74 & $-4.87 * *$ & $-8.09 * *$ & $-1.86 * *$ \\
\hline S.E $($ Sij $) \pm$ & 0.52 & 1.64 & 2.60 & 0.24 & 4.73 & 0.21 & 0.36 & 0.06 & 4.29 & 3.63 & 1.90 & 0.05 \\
\hline $\begin{array}{c}\text { S.E (Sij- } \\
\text { Sik) } \pm\end{array}$ & 0.85 & 2.43 & 3.87 & 0.35 & 7.03 & 0.31 & 0.53 & 0.09 & 6.86 & 5.39 & 2.82 & 0.08 \\
\hline $\begin{array}{c}\text { S.E (Sij- } \\
\text { Skl) } \pm\end{array}$ & 0.69 & 2.27 & 3.62 & 0.33 & 6.57 & 0.29 & 0.50 & 0.08 & 6.15 & 5.04 & 2.64 & 0.08 \\
\hline
\end{tabular}

*** Significant at $5 \%$ and $1 \%$ level of probability, respectively (IUP stands for INDIRA URD PRATHAM) 
Pod length varied from -0.92 to 0.50 in which crosses TU-103 x TU-94-2 (0.50) and MASH-1008 x LBG-623 (0.39) recorded as best specific combiner for trait. Number of seeds pod $^{-1}$ varied from -1.15 to 1.51 among them crosses INDIRA URD PRATHAM $x$ LBG-623 (1.51) and PU-11-14 x LBG-17 (0.85) found as the best specific combiner for the trait. 100 seed weight varied from -1.36 to 1.22 among crosses MASH-1008 x PU-1114(1.22) and TU-103 $x$ INDIRA URD PRATHAM (0.48) registered as best specific combiner for the trait. Biological yield plant ${ }^{-1}$ varied from -18.27 to 28.77 among TU-103 $\mathrm{x}$ LBG-623 (28.77) and MASH-1008 $x$ Indiraurd Pratham (22.38) found as best specific combiner similar results was also reported by Chakraborty et al., (2010).

Seed yield plant ${ }^{-1}$ varied from -7.90 to 11.09 among them crosses TU-103 x LBG-623 (11.09) and Indira Urd Pratham x LBG-623 found best specific combiner for seed yield plant ${ }^{-1}$,Vijay Kumar et al., (2017), Kachve et al., (2015) reported for the same results. Harvest index is varied from -8.09 to 6.37 in which crosses Indira Urd Pratham x LBG-623 (6.37) and PU-11-14 x LBG-623 (3.78) recorded as best specific combiner for trait similar findings were also reported by Ram $e t$ al., (2013) and Chakraborty et al., (2010).

Protein content varied from -3.89 to 2.21 among them crosses Indira Urd Pratham $x$ LBG-623 (2.21) is found as the best specific combiner for traits also reported by Basari et al., (2011). Cross Indira Urd Pratham x LBG623 is found as the best specific combiner for most of the traits including seed yield plant ${ }^{-1}$ and specially for seed yield crosses TU-103 $\mathrm{x}$ LBG-623 (11.09) and Indira Urd Pratham $x$ TU-94-2 (3.48) are also found as best specific combination. The details are given in Table number 3 .

The genotypes like Indira Urd Pratham and
TU-103 were best general combiners for almost all the traits, hence they can be utilized in breeding programmes to generate more diversity in blackgram for development of high yielding genotypes, the best cross combinations for seed yield per plant viz., TU-103 x LBG-623, Indira Urd Pratham $x$ LBG-623 and Indira Urd Pratham x TU-94-2 had positive and significant sca effects for most of the traits. Such promising crosses can be improved through utilization of conventional breeding methods like biparental mating followed by selection through pedigree selection to get the transgressive segregants with higher yield.

\section{References}

Basari, R., Samad, M.A., Deb, A.C. and Khaleque, M.A. 2011. Diallel analysis of soluble protein in root nodules and seeds in blackgram [Vigna mungo (L.) Hepper]. J. Biodiversity Environ. Sci., 1(2): 7-15.

Chakraborty, S., Hironya, K., Borah, B.K., Borah, D.P., Baruah, B.K., Kalita, H. and Barman, Bhubaneswar. 2010. Genetic parameters and combining ability effects of parents for seed yield and other quantitative traits in blackgram [Vigna mungo (L.) Hepper]. Nat. Sci. Biol. 2 (2): 121-126.

Dana, Indrani and Dasgupta, T. 2001. Combining ability in blackgram. Indian J. Genet., 61 (2): 170-171.

Durgaprasad, A.V.S. and Murugan, E. 2015. Combining ability analysis for yield and its attributes in Blackgram (Vigna mungo (L.) Hepper). Electronic J. Plant Breed., 6(2): 417-423.

Griffing, B. 1956. Concept of general and specific combining ability in relation to diallel crossing systems. Aust. J. Biol. Sci., 9: 463-493.

Haque, A.F.M.M., Samad, M.A., Sarker N., Sarker, J.K., Azad, A.K. and Deb, A.C. 2013. Gene effects of some agronomic traits through single cross analysis in blackgram (Vigna mungo L. Hepper) Int. J. Biosci.Vol. 3, No. 6, p. 220-225. 
Kachave, G.A., Parde, N.S., Zate, D.K. and Harer, P.N. 2015. Analysis of combining ability in Blackgram (Vigna mungo (L.) Hepper). International Journal of Advanced Research, Volume 3, Issue 3, 1139-1146.

Kumari, S., Sahai, G., Pandey, K. And Pandey, H. C. 2012. Identification of putative hybrids of cowpea (Vigna unguiculate (L.) Walp.) and their genetic evaluation using RAPD marker. Agric. Sci. Res., 2(9):506- 511.

Nahar, K., Deb A. C., Samad M. A. and Khaleque, M. A. 2010. Genetics study of some agronomical traits through single cross analysis in black gram. Int. J. Sustain. Crop Prod. 5 (3): 22-28.

Panigrahi, K.K. Mohanty, A., Pradhan, J., Das, T.R. and Baisakh, B. 2015. Estimation of Combining Ability in Black Gram (Vigna mungo (L.) Hepper) for Yield and its Attributing Traits Using the Diallel Crossing Method. Electronic Journal of Plant Breeding, 6(3): 651-657.

Patel, S. P., Bharodia, P. S. and Kakade, D. K. 2010. Concept of general and specific combining ability in relation to diallel crossing system. International J. of Agric. Sci., 6(1): 135-137.

Ram, B., Tikka, S.B.S. and Acharya, A. 2013. Heterosis and combining ability in blackgram (Vigna mungo) under different environments. Indian J. Agric. Sci., 83(6): 611-616.

Rameshwari, Netam, C.R., Pandey, R.L. and Nanda, H. C. 2011. Estimates of genetic parameters, heritability and genetic advance for seed yield and its components in urdbean (Vigna mungo (L.) Hepper). Agric. Bio. Res., 27(2): 127-131.
Sarkar, M., Ghosh, S. and Kundagrami, S. 2014. Genetic Variability and Character Association of Yield and Yield Components in Mungbean [Vigna radiata (L.) Wilczek]. J. Agroecol. Nat. Resour. Manage, 1(3):161-165.

Selvam, Y.A. and Elangaimannan, R. 2010. Combining ability analysis for yield and its component traits in Blackgram (Vigna mungo (L.) Hepper). Electronic Journal of Plant Breeding, 1(6):1386-1391.

Sharif, A., Bakhsh, A., Arshad, M., Haqqani, A.M. and Najma, S. 2001. Identification of genetically superior hybrids in chickpea (Cicer arietinum L.). Pak. J. Bot., 33(4): 403-409.

Singh, T.P. and Singh, K.B. 1974. Components of genetic variances and dominance pattern for some quantitative traits in mung bean. Z. Pflazucht, 71: 233-242.

Swindell, R.F. and Poehlman, J.M. 1976. Heterosis in mungbean [Vigna radiata (L.) Wilckzek]. Tropic. Agric., 53: 23-50.

Titumeer, S.M., Rahim, M.A. and Zeba, N. 2014. Genetic Variability, Character Association and Genetic Divergence in Mungbean (Vigna Radiata L.Wilczek). AgronomskiGlasnik, 6: 305-325.

Vijay Kumar, G., Vanaja, M., Babu Abraham, Premkumar, Lakshmi, N. Jyothi and Sarkar, B. 2017. Heterosis and combining ability studies in blackgram (Vigna mungoL. Hepper) under alfisols of SAT region, India. Electronic Journal of Plant Breeding, 8(2): 541-547.

\section{How to cite this article:}

Neeraj Ankur Toppo, S. K. Nair and Abhinav Sao. 2020. Combining Ability Studies in Blackgram (Vigna mungo (L.) Hepper. Int.J.Curr.Microbiol.App.Sci. 9(03): 1423-1431. doi: https://doi.org/10.20546/ijcmas.2020.903.166 